\title{
Intravenous Immune Globulin in Amyopathic Dermatomyositis - Report of Two Cases and Review of the Literature
}

\author{
John M. Cafardi ${ }^{1}$ and Naveed Sami ${ }^{*}, 2$ \\ ${ }^{1}$ The Christ Hospital and The University of Cincinnati Medical Center, USA \\ ${ }^{2}$ Department of Dermatology, The University of Alabama at Birmingham, USA
}

\begin{abstract}
Amyopathic dermatomyositis (ADM) is a rare subtype of dermatomyositis which is often recalcitrant to immune suppressing treatments. Intravenous immunoglobulin (IVIG) has been used in the treatment of refractory dermatomyositis. We present two patients with severe ADM, who were treated with IVIG at $2 \mathrm{~g} / \mathrm{kg}$ every four weeks. Both patients had a successful response and were able to taper the dosage of prednisone. We present both cases in describing IVIG as a rescue and maintenance steroid-sparing agent in the treatment of severe refractory ADM. We also review the treatment of refractory ADM with IVIg in the English literature.
\end{abstract}

Keywords: Intravenous immunoglobulin, treatment, amyopathic dermatomyositis, direct immunofluorescence.

\section{INTRODUCTION}

Amyopathic dermatomyositis is a rare but well described subset of dermatomyositis in which patients develop the characteristic cutaneous lesions of dermatomyositis but clinical or laboratory evidence of muscle disease is absent. As muscle disease in dermatomyositis is typically more responsive to immunomodulatory therapy than cutaneous disease, effective treatments are limited. Here we discuss two cases of refractory ADM (dermatomyositis sine myositis) that responded to IVIG as adjuvant therapy. We briefly review the evidence for the use of IVIG in adult patients with ADM and implications for therapy in the future. Search of the literature was performed with use of PubMed/MEDLINE and Google Scholar, with use of the search terms "amyopathic dermatomyositis", "immune globulin dermatomyositis", "IVIG dermatomyositis" and "IVIG amyopathic dermatomyositis". The bibliography of articles found in the search was also reviewed and included if appropriate. This retrospective study was conducted after obtaining approval from the University of Alabama Institutional Review Board.

\section{CASE \#1}

A $60 \mathrm{y} / \mathrm{o}$ woman with a past medical history significant for hypertension presented for evaluation history of pruritus and a blistering rash. A skin biopsy was performed and demonstrated subepidermal blisters with eosinophilic infiltration. Direct immunofluorescence (DIF) was weakly positive along the base while the indirect immunofluorescence (IIF) was positive for a net-like pemphigus pattern. The main differential diagnoses were blistering drug eruption and paraneoplastic pemphigus.

*Address correspondence to this author at the University of Alabama at Birmingham, 1520 3rd Ave South, EFH 414, Birmingham, AL 35294-0009, USA; Tel: 205-934-5188; Fax: 205-996-7546; E-mail: nsami@uabmc.edu
A comprehensive evaluation for occult malignancy was unremarkable, as were laboratory studies, apart from a mild eosinophilia and a positive anti-nuclear antibody (ANA), with titer 1:1280. Further autoantibody studies, including anti-SSA, anti-SSB and anti-Sm were negative and the patient was diagnosed with bullous drug eruption. Antihypertensive therapy was changed and a prednisone taper was initiated. The rash relapsed whenever the prednisone dose fell below $20 \mathrm{mg}$ daily and dapsone $(150 \mathrm{mg} / \mathrm{d})$ was prescribed for at least eight weeks, without benefit.

She presented one year later with worsening severe pruritus and diffuse erythema over her face, back, chest, eyelids and arms, as well as plaques over the meta-carpal phalangeal (MCP), proximal intra-phalangeal (PIP) and distal intra-phalangeal (DIP) joints of both hands. She denied any other symptoms, specifically weakness, dysphagia, arthralgia or dyspnea. A skin biopsy at this time showed changes consistent with dermatomyositis. Additional laboratory evaluation was unremarkable, apart from a persistently positive ANA that remained positive. Laboratory tests including complete blood count (CBC), metabolic profile, creatinine kinase, serum protein electrophoresis (SPEP) and serum immunofixation (IFE) did not reveal any abnormalities. Tests for autoantibodies to Smith, Sjögren'ssyndrome-related antigen A and B (SSA, SSB), Jo1, Mi2 and P140 (anti-MJ) were negative.

Based on the clinical course, laboratory studies and pathology results, the patient was diagnosed with amyopathic dermatomyositis and corticosteroid sparing was begun, with an attempt to taper off prednisone. She was on each of the following systemic medications for three months without any success: mycophenolate mofetil (MMF- $2 \mathrm{~g} / \mathrm{d}$ ), methotrexate $(15 \mathrm{mg} / \mathrm{wk})$, and sirolimus $(2 \mathrm{mg} / \mathrm{d})$, and hydroxychloroquine $(400 \mathrm{mg} / \mathrm{d})$. Various topical corticosteroids used as adjuvant treatment provided brief temporary relief with pruritus. At this time, therapy with IVIG at a total dosage of 120 grams $(2 \mathrm{~g} / \mathrm{kg}$ over 3 days 
every 4 weeks) was initiated. Eighteen months following initiation of IVIG therapy, prednisone was tapered to $10 \mathrm{mg}$ daily without a flare. Attempt to reduce the frequency of IVIG infusions to every 6 weeks resulted in a flare of skin disease that required an increase in the corticosteroid doses. At this time, her skin disease remains quiescent with IVIG infusions every 4 weeks.

\section{CASE \#2}

A 51 year-old man presented for evaluation of intensely pruritic, erythematous plaques on both hands (MCP and PIP joints), and diffuse erythema of his chest, back and arms. He denied any systemic symptoms, including weakness, dysphagia and dyspnea. Laboratory evaluation, including CBC, metabolic profile, aldolase, creatinine kinase, ANA, SPEP, and serum IFE were within reference ranges. Autoantibodies to Smith, SSA, SSB, Jo1, Mi2, Sc170, perinuclear anti-neutrophil cytoplasmic antibodies (pANCA), cytoplasmic anti-neutrophil cytoplasmic antibodies (cANCA), anti-proteinase 3 (anti-PR3), antimyeloperoxidase (anti-MPO) were negative. A workup for occult malignancy, including whole-body computed tomography (CT), was unremarkable. A skin biopsy was consistent with dermatomyositis.

Following this evaluation, therapy with prednisone $60 \mathrm{mg}$ daily was initiated. Attempts to taper the prednisone below $40 \mathrm{mg}$ /day were unsuccessful, despite the use of azathioprine $150 \mathrm{mg} /$ day and hydroxychloroquine $400 \mathrm{mg} /$ day. In addition to the erythematous plaques described above, he developed several painful, draining non-healing ulcers on his feet and buttocks. Treatment with IVIG at total dosage of 160 grams $(2 \mathrm{~g} / \mathrm{kg}$ over 4 days every 4 weeks) was initiated and within 12 weeks, improvements were noted in the rash and ulcers. The prednisone was tapered to $20 \mathrm{mg} /$ day without any flare in his skin disease.

Following the prednisone taper, he developed severe Raynaud's phenomenon that did not respond to treatment with oral nifedipine and pentoxifylline as well as topical nitroglycerine. He did have a good response to local botulinum toxin in all digits except his index finger, which required partial amputation due to persistent ischemia.

After eight months, the IVIG dose interval was increased to every 6 weeks since his cutaneous disease was well controlled. Shortly after the IVIG interval was increased, he developed spontaneous pneumomediastinum and was diagnosed with interstitial lung disease. The IVIG dose interval was decreased to every 4 weeks and 4 doses of rituximab at $375 \mathrm{mg} / \mathrm{m}^{2}$ were given.

At follow-up one year after the rituximab and IVIG doseadjustment, he has had resolution of his cutaneous disease (rash and ulcers) and improvement of his ILD. He has had no further pneumomediastinum or flares of Raynaud's. He is currently stable on prednisone $5 \mathrm{mg}$ /day, azathioprine 150 $\mathrm{mg}$ /day and hydroxychloroquine $400 \mathrm{mg}$ / day.

\section{DISCUSSION}

Dermatomyositis is a humoral inflammatory disease, with an antibody and complement mediated necrotizing vasculopathy though it is thought that Toll-like receptors (TLR) and type 1 interferon also are involved in pathogenesis $[1,2]$. This is in contrast with polymyositis, which is generally understood to be that of a cellular inflammatory process, primarily mediated by $\mathrm{CD}^{+} \mathrm{T}$ lymphocytes [1].

Dermatomyositis can occur as an idiopathic process, as an association with malignancy, as a drug reaction or in association with another connective tissue disease [3]. Additionally, dermatomyositis can be complicated by ulcerated skin lesions [4] or interstitial lung disease, which is often associated with poor prognosis [5].

The therapeutic approach in dermatomyositis is based on the presence or absence of muscular involvement. Since our patients did not report or demonstrate any clinical symptoms or signs of muscle disease on physical examination and creatine kinase assay was within normal limits, further involvement of muscle disease was not tested. In classical $\mathrm{DM}$, initial therapy consists of $1 \mathrm{mg} / \mathrm{kg}$ prednisone (or equivalent) daily that is continued for at least 6 weeks after clinical and biochemical remission is achieved. Steroid therapy will result in remission of muscle disease in $75 \%$ of patients. The remaining patients require the addition of an additional immunosuppressive agent such as azathioprine, mycophenolate or methotrexate [6]. The cutaneous findings are often more refractory to therapy and frequently do not respond to corticosteroids [6]. As such, an alternative approach to immunosuppressive therapy such as intravenous immune globulin is often required.

In Tables $\mathbf{1}$ and 2, we summarize the published Englishlanguage literature regarding IVIG in amyopathic dermatomyositis from Japan, Spain, France, and the United States which were between the years 2009-2013. Table 2 is separate because of a different degree of detail in the reported cases. In Table $\mathbf{2}$, the treatment course of IVIG was $2 \mathrm{gm} / \mathrm{kg}$, given as $1 \mathrm{gm} / \mathrm{kg}$ every two days and was repeated every three to four weeks. Cases of paraneoplastic amyopathic dermatomyositis were not included.

The cases reviewed show that IVIG in adults is effective as in amyopathic dermatomyositis refractory to standard immunosuppressive regimens. In our review of IVIG as salvage therapy, 35 of 43 patients with amyopathic DM had at least a partial response and 26 of 43 had a significant (complete or nearly complete) response. Additionally, 2 of 6 with concomitant interstitial lung disease had a good clinical response. We believe this is significant, as all had failed to respond to previous intensive immunosuppressive regimens, including systemic glucocorticoids, calcineurin inhibitors and antimetabolites such as azathioprine, mycophenolate and cyclophosphamide. Although the small numbers of patients and the significant population heterogeneity does not allow us to draw definitive conclusions, we believe that the use of IVIG can be considered as adjuvant therapy in amyopathic DM refractory to conventional oral treatments.

Immune globulin therapy has the additional benefit of acting as an immunomodulatory agent rather than an immunosuppressive agent. The mechanism of action is incompletely understood, but is believed to include inhibition of antibody activity and suppression of 
Table 1. Demographics, Clinical response and follow-up to IVIg treatment.

\begin{tabular}{|c|c|c|c|c|c|}
\hline Age/Gender & Associated Findings & Duration of IVIG Therapy & Therapy Prior to IVIG & Therapy After IVIG & Response $^{\#}$ \\
\hline $\begin{array}{l}45 \\
\text { Female [7] }\end{array}$ & ILD & $\begin{array}{c}5 \text { day course } \\
\text { (400 mg/kg/day) total } 2 \mathrm{gm} / \mathrm{kg} \\
\text { Two Courses, one month apart }\end{array}$ & $\begin{array}{l}\text { PSL 60/day } \\
\text { CSA 250/day }\end{array}$ & $\begin{array}{c}\text { PSL taper } \\
\text { (60 to } 20-4 \text { months) } \\
\text { CSA } 250 / \text { day }\end{array}$ & $\begin{array}{c}\text { Survived } \\
\text { (Condition not } \\
\text { otherwise described) }\end{array}$ \\
\hline $\begin{array}{c}72 \\
\text { Male [7] }\end{array}$ & ILD & $\begin{array}{c}5 \text { day course } \\
(400 \mathrm{mg} / \mathrm{kg} / \text { day) total } 2 \mathrm{gm} / \mathrm{kg} \\
\text { One Course }\end{array}$ & $\begin{array}{l}\text { MPD* } \\
\text { PSL 60/day } \\
\text { CSA* } \\
\text { CYC* }^{*}\end{array}$ & $\begin{array}{c}\text { PSL* } \\
\text { CSA* } \\
\text { Polymyxin B } \\
\text { Hemoperfusion }\end{array}$ & $\begin{array}{c}\text { Died } \\
\text { (46 days after onset of } \\
\text { illness) }\end{array}$ \\
\hline $\begin{array}{c}75 \\
\text { Female [7] }\end{array}$ & ILD & $\begin{array}{c}5 \text { day course } \\
(400 \mathrm{mg} / \mathrm{kg} / \text { day }) \text { total } 2 \mathrm{gm} / \mathrm{kg} \\
\text { One Course }\end{array}$ & $\begin{array}{l}\text { MPD* } \\
\text { PSL 50/day } \\
\text { CSA* }\end{array}$ & $\begin{array}{l}\text { PSL* } \\
\text { CSA* } \\
\text { CYC* }\end{array}$ & $\begin{array}{c}\text { Died } \\
\text { (47 days after onset of } \\
\text { illness) }\end{array}$ \\
\hline $\begin{array}{c}55 \\
\text { Female [7] }\end{array}$ & ILD & $\begin{array}{c}5 \text { day course }(400 \mathrm{mg} / \mathrm{kg} / \text { day }) \text { total } \\
2 \mathrm{gm} / \mathrm{kg} \\
\text { One Course } \\
\end{array}$ & $\begin{array}{l}\text { MPD* } \\
\text { PSL 50/day } \\
\text { CSA* } \\
\end{array}$ & $\begin{array}{l}\text { PSL* }^{*} \\
\text { CSA* }^{*} \\
\text { CYC* }\end{array}$ & $\begin{array}{c}\text { Died } \\
\text { (29 days after onset of } \\
\text { illness) } \\
\end{array}$ \\
\hline $\begin{array}{c}24 \\
\text { Male }[7]^{\pi}\end{array}$ & ILD & $\begin{array}{c}5 \text { day course } \\
\text { (400 } \mathrm{mg} / \mathrm{kg} / \text { day) total } 2 \mathrm{gm} / \mathrm{kg} \\
\text { Two Courses, one month apart }\end{array}$ & $\begin{array}{l}\text { MPD 3g } \\
\text { PSL 60/day }\end{array}$ & $\begin{array}{c}\text { CSA } 150 \mathrm{mg} / \text { day } \\
\text { PSL taper }(60 \text { to } 10 \mathrm{mg})\end{array}$ & $\begin{array}{l}\text { Survival, with } \\
\text { resolution of } \\
\text { pulmonary and } \\
\text { cutaneous findings }\end{array}$ \\
\hline $\begin{array}{c}55 \\
\text { Female [8] }\end{array}$ & Calcinosis Cutis & $\begin{array}{c}5 \text { day course }(400 \mathrm{mg} / \mathrm{kg} / \text { day }) \\
\text { total } 2 \mathrm{gm} / \mathrm{kg} \\
\text { Five Courses one month apart, } \\
\text { then one course yearly for } 5 \text { years }\end{array}$ & $\begin{array}{c}\text { Pred 60/day } \\
\text { HCQ 400/day } \\
\text { CLQ 250/day } \\
\text { MTX 7.5/week } \\
\text { AZA 100/day } \\
\text { CSA 200/day } \\
\text { MMF 1500/day }\end{array}$ & $\begin{array}{l}\text { No immunomodulatory } \\
\text { therapy }\end{array}$ & Complete resolution \\
\hline $\begin{array}{c}54 \\
\text { Male [9] }\end{array}$ & ILD & $\begin{array}{c}5 \text { day course }(400 \mathrm{mg} / \mathrm{kg} / \text { day }) \\
\text { total } 2 \mathrm{gm} / \mathrm{kg} \\
\text { One Course }\end{array}$ & $\begin{array}{c}\text { PRED taper } \\
\text { (30 mg over } 12 \text { days) } \\
\text { MPD } 3 \mathrm{~g} \\
\text { PRED 75/day }\end{array}$ & PRED 75/day & Died \\
\hline $\begin{array}{c}61 \\
\text { Female }[10]^{\S}\end{array}$ & None Noted & $\begin{array}{c}2 \text { day course }(1 \mathrm{gm} / \mathrm{kg} / \text { day }) \\
\text { Total } 2 \mathrm{gm} / \mathrm{kg} \\
7 \text { courses, one month apart }\end{array}$ & $\begin{array}{c}\text { HCQ* } \\
\text { PRED 40/day }\end{array}$ & $\begin{array}{c}\text { No immunomodulatory } \\
\text { therapy }\end{array}$ & Complete resolution \\
\hline $\begin{array}{c}29 \\
\text { Female [10] }\end{array}$ & None Noted & $\begin{array}{l}2 \text { day course }(1 \mathrm{gm} / \mathrm{kg} / \text { day }) \\
\text { Total } 2 \mathrm{gm} / \mathrm{kg} \\
28 \text { courses, one month apart }\end{array}$ & $\begin{array}{l}\mathrm{HCQ}^{*} \\
\text { MMF* } \\
\text { MTX* }\end{array}$ & $\mathrm{HCQ}^{*}$ & Complete Resolution \\
\hline $\begin{array}{c}36 \\
\text { Female [10] }\end{array}$ & None Noted & $\begin{array}{c}2 \text { day course }(1 \mathrm{gm} / \mathrm{kg} / \text { day }) \\
\text { Total } 2 \mathrm{gm} / \mathrm{kg} \\
22 \text { courses, one month apart }\end{array}$ & $\begin{array}{l}\mathrm{HCQ}^{*} \\
\text { MTX* }^{*}\end{array}$ & $\begin{array}{c}\text { No immunomodulatory } \\
\text { therapy }\end{array}$ & Complete Resolution \\
\hline $\begin{array}{c}22 \\
\text { Female }[10]^{\S}\end{array}$ & None Noted & $\begin{array}{c}2 \text { day course }(1 \mathrm{gm} / \mathrm{kg} / \text { day }) \\
\text { Total } 2 \mathrm{gm} / \mathrm{kg} \\
6 \text { courses, one month apart }\end{array}$ & $\mathrm{HCQ}^{*}$ & HCQ* & Complete Resolution \\
\hline $\begin{array}{c}53 \\
\text { Female }[10]^{\S}\end{array}$ & None Noted & $\begin{array}{c}2 \text { day course }(1 \mathrm{gm} / \mathrm{kg} / \text { day }) \\
\text { Total } 2 \mathrm{gm} / \mathrm{kg} \\
4 \text { courses, one month apart }\end{array}$ & $\begin{array}{l}\mathrm{HCQ}^{*} \\
\text { MTX* }^{*}\end{array}$ & $\begin{array}{c}\text { No immunomodulatory } \\
\text { Therapy }\end{array}$ & Complete Resolution \\
\hline $\begin{array}{c}93 \\
\text { Female [10] }\end{array}$ & None Noted & $\begin{array}{c}2 \text { day course }(1 \mathrm{gm} / \mathrm{kg} / \text { day }) \\
\text { Total } 2 \mathrm{gm} / \mathrm{kg} \\
4 \text { courses, one month apart }\end{array}$ & $\begin{array}{c}\text { HCQ* } \\
\text { PRED 10/daily }\end{array}$ & $\begin{array}{c}\text { No immunomodulatory } \\
\text { Therapy }\end{array}$ & $>75 \%$ resolution \\
\hline $\begin{array}{c}56 \\
\text { Female [10] }\end{array}$ & None Noted & $\begin{array}{c}2 \text { day course }(1 \mathrm{gm} / \mathrm{kg} / \text { day }) \\
\text { Total } 2 \mathrm{gm} / \mathrm{kg} \\
11 \text { courses, one month apart }\end{array}$ & $\begin{array}{l}\text { HCQ* } \\
\text { MMF* } \\
\text { MTX* }\end{array}$ & $\begin{array}{c}\mathrm{HCQ}^{*} \\
\text { (summer months only) }\end{array}$ & $>75 \%$ resolution \\
\hline $\begin{array}{c}87 \\
\text { Female [10] }\end{array}$ & None Noted & $\begin{array}{c}2 \text { day course }(1 \mathrm{gm} / \mathrm{kg} / \text { day }) \\
\text { Total } 2 \mathrm{gm} / \mathrm{kg} \\
9 \text { courses, one month apart }\end{array}$ & $\mathrm{HCQ}^{*}$ & None & $<75 \%$ resolution \\
\hline $\begin{array}{c}58 \\
\text { Male [10] }\end{array}$ & None Noted & $\begin{array}{c}2 \text { day course }(1 \mathrm{gm} / \mathrm{kg} / \text { day }) \\
\text { Total } 2 \mathrm{gm} / \mathrm{kg} \\
7 \text { courses, one month apart }\end{array}$ & $\begin{array}{c}\text { HCQ* } \\
\text { THAL* } \\
\text { MTX* } \\
\text { PRED 40/day }\end{array}$ & PRED 20/day & $<75 \%$ resolution \\
\hline
\end{tabular}

Key:

\# Clinical Response, as described by the authors. When percentages are given, they represent the Cutaneous Dermatomyositis Disease Activity and Severity Index (CDASI)

* Drug dosage, route and/or schedule not given in text

If This patient was classified by the authors as amyopathic dermatomyositis, He had no clinical muscular symptoms and normal EMG. This patient did, however, have small elevations in CK and aldolase at initial presentation, which normalized with initial glucocorticoid therapy and remained within normal limits throughout the remainder of his described course

$\S$ Diagnosis described by authors as "provisional" amyopathic dermatomyositis, which is not defined in the text

Drug Abbreviations:

AZA - Azathioprine; CLQ - Chloroquine; CSA - Cyclosporine A; CYC - Cyclophosphamide; HCQ - Hydroxychloroquine; MMF - Mycophenolate Mofetil; MPD -

Methylprednisolone; MTX - Methotrexate; PRED - Prednisone; PSL - Prednisolone; THAL - Thalidomide. 
Table 2. Baseline characteristics of this population are summarized belo.: All data are from Bonfour et al. [11].

\begin{tabular}{|c|c|c|c|c|c|c|}
\hline $\begin{array}{c}\text { Gender } \\
\text { Distribution }\end{array}$ & $\begin{array}{c}\text { Age (y) } \\
\text { Mean } \\
\text { [Range] }\end{array}$ & Classification & $\begin{array}{c}\text { Associated } \\
\text { Malignancy }\end{array}$ & ILD & $\begin{array}{c}\text { Therapy Prior } \\
\text { To IVIG }\end{array}$ & $\begin{array}{c}\text { Time Until Initiation of } \\
\text { Glucocorticoids } \\
\text { (Mean/Range - Months) }\end{array}$ \\
\hline \hline & & & & & TGC: $11(41 \%)$ & TAC: $2(7 \%)$ \\
$3 \mathrm{M}$ & 52 & ADM: $10(37 \%)$ & & SGC: $11(41 \%)$ & 34 \\
$24 \mathrm{~F}$ & $(25-90)$ & hDM: $6(22 \%)$ & \multirow{2}{*}{$5(19 \%)$} & $3(11 \%)$ & HCQ: $14(52 \%)$ & $(4-240)$ \\
& & CR-CDM: $6(22 \%)$ & & & MTX: $3(11 \%)$ & AZA: $1(4 \%)$ \\
\end{tabular}

Clinical response and follow-up treatment are summarized below:

\begin{tabular}{|c|c|c|c|c|c|c|c|}
\hline $\begin{array}{l}\text { IVIG Courses } \\
\text { (Mean/Range, in } \\
\text { Months) }\end{array}$ & $\begin{array}{c}\text { Response to } \\
\text { IVIG (N - \%) }\end{array}$ & $\begin{array}{l}\text { Therapy } \\
\text { Concurrent } \\
\text { with IVIG }\end{array}$ & $\begin{array}{c}\text { Additional } \\
\text { Therapy if } \\
\text { NR/PR }\end{array}$ & $\begin{array}{l}\text { Relapse } \\
\text { Among } \\
\text { SR }\end{array}$ & $\begin{array}{c}\text { IVIG } \\
\text { Treatment } \\
\text { of Relapse } \\
\text { in SR }\end{array}$ & $\begin{array}{c}\text { Clinical Course After } \\
\text { IVIG Treatment of } \\
\text { Relapse }\end{array}$ & $\begin{array}{c}\text { Progression to } \\
\text { CDM }\end{array}$ \\
\hline $\begin{array}{l}\text { All: } 4.8(1-15) \\
\text { SR: } 5.3(3-15)\end{array}$ & $\begin{array}{c}\text { NR: } 4(15 \%) \\
\text { PR: } 4(15 \%) \\
\text { SR: } 19(70 \%)\end{array}$ & $\begin{array}{l}\text { All: } 17(63 \%) \\
\text { TAC: } 2(7 \%) \\
\text { CLQ: } 1(4 \%) \\
\text { HCQ: } 9(33 \%) \\
\text { SGC: } 6(22 \%)\end{array}$ & $\begin{array}{c}\text { SGC: } \\
7(26 \%) \\
\text { MTX: } 1(4 \%) \\
\text { MMF: } 1(4 \%) \\
\text { HCQ: } 2(7 \%)\end{array}$ & $10(53 \%)$ & $6(60 \%)$ & $\begin{array}{l}\text { Required Multiple } \\
\text { courses of IVIG: } 3 / 6 \\
\text { Treatment following } \\
\text { IVIG Retreatment } \\
\text { SGC=2, MTX=2 } \\
\text { TGC=2 }\end{array}$ & $\begin{array}{c}6 / 27(22 \%) \\
\text { 0/9 non-relapsed SR } \\
\text { 2/10 relapsed SR } \\
\text { 4/8 NR or PR }\end{array}$ \\
\hline
\end{tabular}

Key:

ADM: Amyopathic Dermatomyositis: Cutaneous findings for at least 6 months, without clinical or laboratory evidence of muscle disease

hDM: Hypomyopathic Dermatomyositis: Cutaneous findings with subclinical muscle disease (i.e. asymptomatic and normal exam with abnormal muscle enzymes and/or abnormal EMG)

pDM: Premyopathic Dermatomyositis: Cutaneous findings for less than 6 months, without clinical or laboratory evidence of muscle disease

CR-CDM: Cutaneous relapse of Classical Dermatomyositis (relapse involving only cutaneous manifestations, with previous muscle involvement)

ILD: Interstitial Lung Disease; TGC: topical glucocorticoids; TAC: topical tacrolimus; SGC: Systemic Glucocorticoids; CLQ: Chloroquine; HCQ: Hydroxychloroquine; MTX: Methotrexate; MMF: Mycophenolate Mofetil; AZA: Azathioprine; SR: significant response, defined by the investigators as a complete or near-complete response; NR: no response; PR: Partial Response.

inflammatory cytokine secretion [12]. Of particular interest, IVIG has been noted to have efficacy in steroid-resistant cases and has demonstrated efficacy in treatment of dermatomyositis [13]. Although expensive, its costs should be balanced with the long-term adverse effects of steroids, antimetabolites and calcineurin inhibitors. Additional adverse effects of IVIG include nephrotoxicity with high or repeated doses, however newer formulations appear to have a reduced incidence of renal toxicity, which make this a more appealing option [14].

\section{CONCLUSION}

Both our cases support the use of IVIG for ADM that is refractory to standard therapy, both with and without interstitial lung disease. Further data is needed to better understand the role and timing of IVIG in therapy of ADM.

\section{CONFLICT OF INTEREST}

The authors confirm that this article content has no conflict of interest.

\section{ACKNOWLEDGEMENTS}

Declared none.

\section{REFERENCES}

[1] Dalakas MC, Hohlfeld R. Polymyositis and dermatomyositis. Lancet 2003; 362: 971-82.

[2] Gherardi RK. Pathogenic aspects of dermatomyositis, polymyositis and overlap myositis. Presse Med 2011; 40: e209-18.

[3] Callen JP. Dermatomyositis. Lancet 2000; 355: 53-7.

[4] Shimojima Y, Ishii W, Kato T, et al. Intractable skin necrosis and interstitial pneumonia in amyopathic dermatomyositis, successfully treated with cyclosporin A. Intern Med 2003; 42: 1253-8.

[5] Neuhaus IM, Connolly MK. An unusual presentation of amyopathic dermatomyositis associated with fatal interstitial lung disease. Arch Dermatol 2006; 142: 113-4.

[6] Callen JP, Wortmann RL. Dermatomyositis. Clin Dermatol 2006; 24: $363-73$

[7] Suzuki Y, Hayakawa H, Miwa S, et al. Intravenous immunoglobulin therapy for refractory interstitial lung disease associated with polymyositis/dermatomyositis. Lung 2009; 187: 201-6.

[8] Penate Y, Guillermo N, Melwani P, Martel R, Hernandez-Machin B, Borrego L. Calcinosis cutis associated with amyopathic dermatomyositis: response to intravenous immunoglobulin. J Am Acad Dermatol 2009; 60: 1076-7.

[9] Chaisson NF, Paik J, Orbai AM, et al. A novel dermato-pulmonary syndrome associated with MDA-5 antibodies: report of 2 cases and review of the literature. Medicine (Baltimore) 2012; 91: 220-8.

[10] Femia AN, Eastham AB, Lam C, Merola JF, Qureshi AA, Vleugels RA. Intravenous immunoglobulin for refractory cutaneous dermatomyositis: a retrospective analysis from an academic medical center. J Am Acad Dermatol 2013; 69: 654-7. 
[11] Bounfour T, Bouaziz JD, Bezier M, et al. Clinical efficacy of intravenous immunoglobulins for the treatment of dermatomyositis skin lesions without muscle disease. J Eur Acad Dermatol Venereol 2014; 28(9): 1150-7.

[12] Gelfand EW. Intravenous immune globulin in autoimmune and inflammatory diseases. N Engl J Med 2012; 367: 2015-25.
[13] Dalakas MC, Illa I, Dambrosia JM, et al. A controlled trial of highdose intravenous immune globulin infusions as treatment for dermatomyositis. N Engl J Med 1993; 329: 1993-2000.

[14] Chapman SA, Gilkerson KL, Davin TD, Pritzker MR. Acute renal failure and intravenous immune globulin: occurs with sucrosestabilized, but not with D-sorbitol-stabilized, formulation. Ann Pharmacother 2004; 38: 2059-67.

Received: April 23, 2015

Revised: September 23, 2015

Accepted: September 23, 2015

(C) Cafardi and Sami; Licensee Bentham Open.

This is an open access article licensed under the terms of the Creative Commons Attribution Non-Commercial License (http://creativecommons.org/licenses/by-nc/ 3.0/) which permits unrestricted, non-commercial use, distribution and reproduction in any medium, provided the work is properly cited. 